\title{
A Record of Myotis nathalinae Tupinier, 1977 from Poland
}

\author{
NOCEK SZARY MYOTIS NATHALINAE TUPINIER, 1977, NOWY SSAK \\ DLA FAUNY POLSKI
}

\author{
Wiesław BOGDANOWICZ \& Zbigniew URBAŃCZYK
}

\begin{abstract}
Bogdanowicz W. \& Urbańczyk Z., 1981: A record of Myotis nathalinae Tupinier, 1977 from Poland. Acta theriol., 26, 28: 427 [With 1 Fig.].

[Dept. Syst. Zool., A. Mickiewicz Univ., Fredry 10, Poznań (W. B.) and Dept. Biol., Acad. Physical Education, Marchlewskiego 27/39, Poznań (Z. U.)]
\end{abstract}

Myotis nathalinae Tupinier, 1977, recently described from Southern Spain, has hitherto been known from only a small number of places in Spain, France and Switzerland (Tupinier, 1977; Aellen, 1978; Hutterer, 1978). It differs from the very similar $M$. daubentoni Kuhl, 1819, in respect of smaller dimensions, a greyer colour of coat and absence of protoconus on $P^{4}$ and a distinct nodule on the dorsal side of the baculum (Tupinier, 1977).

Ruprecht (in press) has given several stations of this bat, of rank of morphotypes, from Poland.

Fig. 1. Difference in structure of $P^{4}$ in $M$. nathalinae (A) and $M$. daubentoni (B).

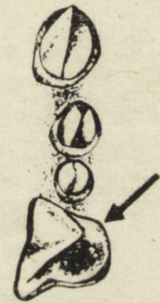

A

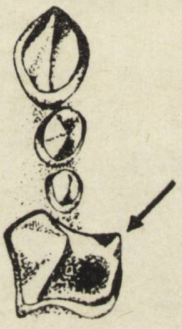

B

On 30th January 1980 the remains of the bat Myotis nathalinae were found in the underground corridors of old fortifications in the Lubuskie Lake District, near the village of Wysoka, in the Gorzów voivodship $\left(52^{\circ} 23^{\prime} \mathrm{N}, 15^{\circ} 28^{\prime} \mathrm{E}\right)$ (UTM WU 30). It was identified by means of the tooth structure, i.e., the absence of protoconus on $P^{4}$ and the rounded shape of the cingulum (Fig. 1). The following craniometric measurements were made on the skull: $\mathrm{Cb}$. $-13.4 \mathrm{~mm}, \mathrm{C}_{-} \mathrm{M}^{3}$ length $-5.3 \mathrm{~mm}$, interorbital breadth $-4.0 \mathrm{~mm}$, mastoidal breadth $-7.6 \mathrm{~mm}$, mandibular length $-10.3 \mathrm{~mm}$. Forearm length was $35.2 \mathrm{~mm}$.

The underground passages in the Lubuskie Lake District constitute a new station of $M$. nathalinae in Central and Eastern Europe.

The authors would like to take this opportunity of expressing their grateful thanks to Dr. Yves Tupinier for checking the correctness of identification.

\section{REFERENCES}

Aellen V., 1978: Les chauves-souris du Canton de Neuchatel, Suisse (Mammalia, Chiroptera). Bull. de Soc. neuchătel. Sci. nat., 101: 5-26. - Hutterer R., 1978: Ein weiterer Nachweis der kleinen Wasserfledermaus, Myotis nathalinae Tupinier, 1977. Bonn. zool. Beitr., 29: 1-3. - Ruprecht A. L. in press: Chiroptera [In: "Atlas rozmieszczenia ssaków w Polsce" Eds Pucek Z., Raczyński J.]. - Tupinier Y., 1977: Description d'une chauvesouris nouvelle: Myotis nathalinae nov. sp. (Chiroptera-Vespertilionidae). Mammalia, 41, 3: 327-340. Accepted, March 20, 1981. 